\title{
Constructive Principle of Religious Style: Ontological Basis ${ }^{a}$
}

\author{
Tatiana V. Itskovich, Anna V. Shutaleva* \\ Ural Federal University, Ekaterinburg, Russian Federation
}

\begin{abstract}
To the present day, the linguistic description of the religious style is reduced to characterizing certain genres, such as preaching, prayer, message, hagiography. The choice of the constructive principle of religious style and the description of its ontological foundations have not yet been set as an objective scientific study. The review demonstrates how the idea of prototextualism of religious style is advanced and, consequently, the protogenic conditioning of all modern religious genres. The idea of proto-textualism receives a communicative, pragmatic and categorical textual basis in this review. The constructive principle of religious functional style is determined by the peculiarities of religious consciousness and religious activity. The characterization of these ontological principles of dual peace and salvation lies in the notion of the text-sphere embodied in the constructive principle of proto-textuality, which implies the obligatory support of each of the following religious texts relating to the religious prototype.
\end{abstract}

\footnotetext{
a Supported by Act 211 Government of the Russian Federation, agreement № 02.A03.21.0006.

The reported study was funded by RFBR according to the research project №18-012-00382 A.
}

\section{Introduction}

In the last decades of the 20th century, religion returns to its place of significant social consciousness. A paradoxical situation existed in Russian linguistics. Namely, due to the historically established social relations in Russia of the 20th century, religion was not considered as a sphere of public consciousness, which is inherent in a certain style. This incident is the fact of the subordination of science to the ideological attitudes of the time. Like other linguistic styles, the language of the religious life of society is characterized by a full set of style-forming grounds, such as a special form of public consciousness and the type of activity, specific goalsetting of speech communication, a set of independent genres-text types.

In the 80 years of the 20th century, the social situation in the post-Soviet space changed, which led to the actualization of the issue of the allocation of a separate style that corresponds to religion as a form of public consciousness. The current situation makes it possible to raise the question of the status of this type of speech activity, where religious and preaching style should take its proper place in the functional-stylistic paradigm of the modern Russian literary language and be appropriately described in the literature on stylistics [1].

A public consciousness is the views of people in their totality on the phenomena of nature and social reality, expressed in the natural or artificial language created by society, the creations of spiritual culture, social norms and views of social groups, the people and humanity as a whole. Correlation with the existing system of functional styles makes it possible to distinguish the following forms of social consciousness: political, legal, moral, religious, aesthetic, scientific consciousness. The basis for this classification is the subject and form of reflection, social function, the nature of the laws of development, and the degree of dependence on social being. Public consciousness has a complex structure and various levels, for example, every day, theoretical, conceptual.

The phenomenon of public consciousness is difficult to analyze because it is a bobbed phenomenon of the spiritual life of society. It is difficult to unravel the living system of spiritual life and trace the intertwining of its individual threads-moral and philosophical motives and ideas.

\section{Problem Statement}

Socio-cultural changes in the modern world have led to a sharpening of attention to the problems of intercultural interaction, in which the issues of communication of representatives of various religious movements are important. A large number of modern studies are devoted to various problems related to issues of religion and religious communication [2, 3, 4, 5, 6, 7].

In Russia, scientific research of religion and religious communication was actualized. In the paradigm of the functional styles of the Russian literary language, the

Corresponding author: a.v.shutaleva@urfu.ru 
study of verbal and textual features of religious style is one of the current trends in modern linguistics $[8,9,10]$.

In the Russian literary language, the traditional paradigm of functional styles is enriched with a religious functional style that fully complies with special extralinguistic criteria. Religious consciousness and related actions are the main extralinguistic grounds for the difference of religious functional style.

\section{Purpose of the Study}

The purpose of the article is the study of the specifics of religious consciousness, directly influencing the system of genre organization of religious style. Religious consciousness at the ordinary level appears as fragmentary, disjointed images, representations, stereotypes, attitudes, moods, habits and traditions. At this level, the main role is played by emotions, namely feelings and moods, visually shaped forms of consciousness. Ordinary religious consciousness is represented in the genre picture of religious style through personal, namely, non-canonical prayers, spiritual hymns, noncanonical akathists, variants of life.

\section{Research Methods}

The theoretical and methodological basis of this study is the idea of the typical genres of religious style acquires specific features in the conditions of everyday life, that lead to the appearance of genre variations, namely subgenres. This is relevant for everyday consciousness. Canonical prayer is the basis for personal prayer; an akathist can be the basis for a non-canonical version of this genre.

As the analysis shows, these variants have a common compositional structure, but they differ significantly in the content filling of composite circuits, in their lexical design and leading tonality. Texts of various genres of religious style, which embody ordinary religious consciousness, are on the periphery of the genre field because in an incomplete or altered form they translate the concepts of the proto-text.

The main methodological concept is the proto-text. The proto-text is a complete closed canonical text conveying the words of God or prophets and in a concentrated form containing the values and meanings of a particular confession. Proto-text contains the definitions and patterns that form the proper behavior of the person. Proto-text is a materially signified fixed base, to which the subject refers. A person living in a religious system of coordinates thinks and acts in accordance with the principles of the sacred world, in any other sphere, namely, in science, politics, philosophy, art. Any event, act, fact, word, though in the terrestrial a priori sinful space is verified by the principles given in the prototype.

\section{Findings and discussion}

Religious consciousness on a theoretical, conceptual level is an integrated set of concepts, ideas, principles.
Religious consciousness rests on the dogmas of faith, as a rule, framed in the canon, a set of religious provisions. The dogma is the affirmation by the highest religious institution of the position of the dogma as unchangeably true. The structure of the canon includes an orderly teaching about God, the world, nature, society, man, ritual prescriptions [11].

The conceptual level of religiosity is based on the prototype, while at the same time, rules for its interpretation are being developed. Representing the conceptual religious consciousness genres are close to the proto-text and they most fully and correctly reflect the concepts, principles, ideas contained in it. Religious experience is another important component of religious consciousness, which, in our opinion, can not be attributed either to the conceptual level or to the ordinary. Religious experience is embodied in meditation, ecstasy, mystical visions, contemplation of God.

Religious consciousness is radically different from other forms of social consciousness by the specificity of functional realization. The following functions of religion are significant from a philosophical point of view. The illusory and compensatory function of religion is due to the fact that religion gives a person hope for comfort and moral satisfaction. The worldview function is to create a religion of its own picture of the world. Regulatory function is to establish a religion of the system of norms and values, and thus religion regulates human behavior. Communicative function of religion is embodied in the organization of communication of believers.

The specificity of the realization of these functions of religion is determined by the recognition of the existence of two worlds, namely, the real world, the terrestrial and the world of the other world, heavenly, spiritual. The spiritual world is the ultimate meaning of human being and determines its value-semantic orientation. Religion means believing in the reality of an absolutely valuable, recognition of the beginning in which the real power of being and the ideal truth of the spirit are brought together [12]. The ontological principle of dual reality in the religious worldview determines the specificity of the linguistic constructive principle of religious style.

The fundamental religious ontological principle of dual reality is also reflected in such distinctive features of religious style as bilingualism and reverential tonality. In different faiths, the tradition of using different languages in dealing with the subjects of the transcendental and terrestrial realities is a tradition. Traditionally sacred language is used in worship, in the informal religious situation profane language is used. Missionary goals have led to the existence of a tendency to reduce the share of the use of the sacred language in the liturgical sphere and replace it with profane language.

Communication with the subjects of the transcendental reality is a communication with the bearers of the absolute ideal, which causes the use of a reverent key, regardless of the language used. The emergence of a personality-trusting tone indicates a reduction in distance, which is possible only in an 
informal setting, for example, in personal prayer. Such texts are on the periphery of the genre field of religious style.

Religion occupies a special place among other philosophical knowledge spheres of social consciousness. Religion, like science, politics, art, law, forms the worldview of the subject. Religion not only determines the specificity of religious activity but also dictates the features of the functioning of the individual and society in other spheres of human activity.

Functional style, in addition to the form of social consciousness, is determined by the type of human activity. Czech linguist $\mathrm{C}$. Gausenblas defines the style in the most general sense of the word as a specific way of pursuing the purposeful activity that provides for the specificity and structure of this activity [13]. In Guiraud's definition, it is emphasized that style designates a specific mode of action [14].

Religious activities have a specific character. Religious studies offer the following classification of religious activity. The dichotomy of non-religious and religious activity of religious people, groups, organizations is singled out. Non-religious activities are activities in the economic, industrial, political, artistic, and scientific fields. Such activities can be religiously colored, but in terms of objective content, subject and results, it is outside of religion.

Actually, religious activities are divided into extracurricular and cultic. Extracurricular activities are carried out in the spiritual and practical spheres. The spiritual sphere is the development of religious concepts, the systematization, and interpretation of the dogmas of theology, the writing of theological works. Varieties of practical extracurricular activities include the production of religious worship, missionary work, teaching theological disciplines in educational institutions, propaganda of religious views $[11,15]$.

Religious activities are sets of religious activities that are defined by the canon and aimed at serving God. The content of religious activity is determined by the prototext. Reproduction of the events of the proto-text during worship is "the supreme reality" because it provides communication with the transcendent world. During the service, genres are used as closely connected with the proto-text and aimed at the transformation of human nature, namely, deification, or salvation. A man has a goal above the created world, namely his connection with God is a being destiny. It can be argued that all genres of religious style are aimed at achieving a supergoal by man, namely, the salvation of the soul.

The fundamental and specific feature of religious consciousness is the desire of the subject to approach God, to find unity with the transcendental essence. In Christianity, this desire is defined as salvation, understood as the maximum possible for each subject approach to God after the end of earthly life. The salvation intensity is global and meaningful, which determines all other goals of the subject. All other goals of religious communication and activity are subject to the intention of salvation.

The pursuit of salvation presupposes different degrees of responsibility both for oneself and for others, determined by social status, and by a personal level of spiritual development. So, the priest is responsible for saving parishioners, husband and father for saving family members. Regardless of the social status, any person is responsible for preserving the spiritual balance of people who are nearby. Hence the maximum degree of responsibility of a person for the words he says and his actions.

The aspiration of the subject to salvation, his constant reference to sacral values determine his behavior in the earthly world. The spirit of salvation determines the thought, word and deed of a religiously oriented person in any field of activity, in particular, the idea embodied in the word that leads to action. Religious activities, determined by the desire for salvation, form the features of communication in the religious sphere, the activity determines the speech tools used.

Specific features of religious activity determine two directions in the intentional area of the corresponding style. When communicating with representatives of the sacred world, praise, gratitude and a request are used. When communicating with representatives of the profane world, information, clarification, edification are used.

By reuniting the life of the natural-social and transcendent worlds, religion is distinguished by the peculiarity of spiritual activity. Namely, the earthly man strives for the transcendental, with this personal salvation is connected. The search for the foundations of his own being prompted I. Kant to the idea that "Two things fill the soul always with a new and more powerful surprise and reverence, the more often and more often we reflect on them - this starry sky above me and the moral law in me" [16].

Thus, the religious consciousness, which is based on the idea of double reality, and religious activity directed in one form or another to salvation, are ontological grounds for distinguishing the constructive principle of religious style.

The concept of "constructive principle" was introduced into the everyday life of the functional stylistics of V.G. Kostomarov [17, 18]. The constructive principle is understood as the leading principle of selection of linguistic means and their textual organization, conditioned by the basic extralinguistic style-forming factors [19, p. 180]. The constructive principle defines the basic style features, which, in turn, are realized through a set of linguistic features [19, p. 404].

The constructive principle of religious functional style is determined by the peculiarities of religious consciousness and religious activity. Religious worldviews determine the principle of the duality of reality in its objective-static aspect and the principle of salvation in its subjectively dynamic aspect. These principles in the projection on the text-sphere are embodied in the constructive principle of prototextuality, implying the obligatory for each of the subsequent religious texts reliance on religious prototext.

Religious ideas about the world of the earthly and heavenly, about the place and path of man in it in the 
world religions are fixed in the corresponding proto-texts $[20,21]$. Such proto-texts for traditional denominations are the following. Vedas, Brahmanas, Upanishads are proto-texts in the Vedic religion. Tanah, Torah is the prototypes in Judaism. Avesta is a proto-text of Zoroastrianism. I Ching (Book of Changes), Conversations and Judgments are prototypes of Confucianism. Tripitaka is the proto-text of Buddhism. Tao Te Ching is the proto-text of Taoism in Christianity. The Bible is the proto-text of Christianity. The Koran is the proto-text of Islam [9].

The life of a subject in a religious system of coordinates proceeds successively in two worlds. One world is the "earthly", profane world. The heavenly world is another world and it is defined as a celestial, sacred. A life in the terrestrial world is oriented to the values peculiar to the heavenly world. The reality of the religious worldview is based on the idea that the entire universe is the establishment and manifestation of God. Therefore, the world appears as a symbolic "doubled" space, which implies from the person the ability to perceive reality in particular. Contemplation of a picture, icon, sculpture suggests that a person can move from one plan to another, which is, move from the world of the earth into the sacred world through a symbolic worldview.

The fundamental hermeneutic category of "understanding" is significant for religious communication. Understanding is connected with faith. Understanding and faith simultaneously mediate and precede each other, because, in order to understand an object, one must know the object of understanding, but to know it, one must believe.

"Believing and understanding" is a formula proclaimed by Christian medieval thinkers. Appeal to this formula today returns to the realization of the idea of harmony of faith and reason, for understanding tends to consistency, and, therefore, to the harmonization of the logical application of reason and the contemplativegnostic, emotional component inherent in a religious event.

For Christians, the principles of the heavenly world are formulated in the text of Scripture, which is a prototype. In the texts of Holy Scripture and the Sacred Tradition, God's speech to people is recorded, as well as an event series showing the path to salvation. This problem arises in modern scientific discourse as a problem of interpretation and attempts to return to the biblical understanding of the terms of Holy Scripture [22, 23, 24]. The collection of texts of Holy Scripture and Sacred Tradition is a guide that sets the ideal and determines the speech-activity of a person.

\section{Conclusion}

Any kind of communication in the religious sphere is genetically derived from the prototype of Holy Scripture and Sacred Tradition and relies on them. The Proto-text of Holy Scripture is a closed semantic formation, initially exhausting the body of real texts.
The persons described in the Holy Scriptures are subjects of the proto-text that act in a certain historical objective-sacred time and space. In the prototype, invariant genre models that correspond to the goals of participants in religious communication during a particular historical period are fixed, and the protagonists of prayer, sermons and lives are immanently given. Each proto-genre is a text invariant, the basic initial basis of the genre.

Protogens are further developed, transforming into a modern genre system of religious functional style. The genre peculiarity of the texts created in the space of religious communication is determined by the proximity to the prototype and the degree or level of its reflection in the text being created. As applied to the genre level, this ratio is expressed in the genetic connection of later texts with genre proto-text. These genre samples not only set the canon of the genre but also are actively used in modern religious communication.

Thus, the ontological basis of a religious style is the dual reality, and salvation is the main intention of religious text-generation. Philosophical understanding of dual reality as a distinctive feature of religious consciousness is realized in religious style through proto-textuality.

Proto-textuality is a constructive feature of the religious functional style, which determines the binding indissoluble bond of all genres-text-types with protogens. Continuity and safety of canonical ideological constructs are provided and in a concentrated form is contained in protests. The ideological and content proximity to the prototype, following the canons defined in it, determines the field structure of genres of religious style, their nuclear or peripheral affiliation.

\section{References}

1. L.P. Krysin, Vestnik akademii nauk SSSR 8, 49-55 (1986)

2. F. Antonelli, E. Ruspini, Religion society-journal of social sciences of religion 32 (88), 17-30 (2017)

3. M. Bastos, P. Bastos, I. Osório, D. Iandoli, G. Lucchetti, Transcultural Psychiatr, 55(2), pp. 286313 (2018)

4. J. Morris, Islam and Christian-Muslim Relations 29(2), 167-191 (2018)

5. D.R. Van Tongeren, E.L. Worthington, D.E. Davis, J.N. Hook, C.A. Reid, R.C. Garthe, Psychology of religion and spirituality $\mathbf{1 0 ( 1 ) , ~ 5 5 - 6 2 ~ ( 2 0 1 8 ) ~}$

6. J.L. Woods, D.J. Hensel, Journal of religion \& health 57(2), SI, 636-648 (2018)

7. T.V. Itskovich, In the World of Scientific Discoveries, Series A 3(1), 59-74 (2015)

8. T.V. Itskovich, In the world of scientific discoveries 9.2 (57), 760-784 (2014)

9. N.B. Mechkovskaya, Russian linguistics 25(1), 85103 (2001)

10. N.B. Mechkovskaya, Russian linguistics 29(1), 49$70(2005)$ 
11. V.I. Garadzha, Russian studies in philosophy 33(1), 65-67 (1994)

12. S. Frank, Reality and Man. An Essay on the Metaphysics of Human Nature. Translated by Natalie (Duddington. New York: Taplinger) (1950)

13. K. Hausenblas, Zeitschrift fur Slawistik 29(1-3), 381-389 (1984)

14. P. Guiraud, La stilistique (Coll. “Que sais-je?”). P. PUF. (1963)

15. I.N. Yablokov, Questions of philosophy 1, 49-59 (2012)

16. I. Kant. Critique of Pure Reason (Hackett: Indianapolis, IN/Cambridge 1996)

17. V.G. Kostomarov, Reasons and character of progress of Russian language in our days, Vestnik akademii nauk SSSR 10, 89-100 (1978)

18. V.G. Kostomarov, E.M. Verescagin, Slavic and east European Journal 19(1), 40-48 (1975)

19. M.N. Kozhina, Stylistic encyclopedic dictionary of the Russian language. (Moscow, 2003)

20. E.A. Torchinov, Philosophy East \& West 42(2), 327-333 (1992)

21. World Religions, Britannica Enciclopedia of World Religions, 1148 (2006)

22. A. Case, Bible translator 68(3), 269-283 (2017)

23. E.A. Stepanova, Questions of philosophy 4, 5060 (2017)

24. W. Brueggemann, Theology Today 74(4), 340-346 (2018) 